\title{
CARBOHYDRATE DEGRADATION OF TUBER PASTE FLOUR BY THE ADDITION OF a-AMYLASE FROM TWO Lactobacillus SPECIES
}

\author{
[Penguraian Karbohidrat Tepung Pasta Umbi dengan Penambahan \\ a-Amilase dari Dua Spesies Lactobacillus]
}
Tatik Khusniati ${ }^{1) \star}$, Gadis Trieska Dewi ${ }^{2)}$, Anna P. Roswiem ${ }^{2)}$, Suci Ayu Azhari ${ }^{2)}$, Febi Ishfahani ${ }^{2)}$, and Sulistiani ${ }^{1)}$

\footnotetext{
1) Microbiology Division, Research Center for Biology, Indonesian Institute of Sciences, Cibinong Science Center, Bogor 2) Pharmacy Study Program, Industrial Technology and Pharmacy High School, Bogor
}

Received May $18^{\text {th }} 2018 /$ Accepted April $16^{\text {th }} 2020$

\begin{abstract}
The quality of Indonesia tuber flour can be improved by a-amylases which hydrolyzes the flour amylose to glucose and maltose. These monosaccharides causes the flour to have better homogeniety similar to wheat flour and easier to digest. This research aimed at investigating carbohydrate degradation of tuber paste flour by the addition of $\alpha$-amylase from two Lactobacillus species. Lactobacillus species used were Lactobacillus bulgaricus and L. plantarum B110, while the flour types were made of local taro (Colocasia esculenta), gadung (Dioscorea hispida) and sweet potato (Ipomoea batatas), as well as wheat (Triticum) as a reference. Crude $\alpha$-amylase activity and reducing sugars were detected by the Dinitrosalycylic acid (DNS) method. Data were statistically analyzed with ANOVA. Research results indicated that $\alpha$-amylase from L. bulgaricus and L. plantarum B110 have been characterized for their optimum activity and stabilitiy. The reducing sugar content in taro, gadung, sweet potato paste flour and wheat paste flour added with $\alpha$-amylase of $L$. bulgaricus increased by $0.008,0.006,0.004$ and $0.001 \%$, respectively. Meanwhile, the reducing sugars of the above flours added with amylase from $L$. plantarum B110, increased by $0.008,0.008,0.008$, and $0.003 \%$, respectively. Increase in reducing sugar contents in carbohydrate degradation of local tuber paste flour added with L. bulgaricus a-amylases was higher than that in wheat paste flour with a $0.001 \%$ increase. Similarly, the $0.008 \%$ increase of sugar content in tuber paste added with L. plantarum B110 a-amylase was also higher than that in wheat flour with $0.003 \%$ increase. Therefore, local tuber paste flour can be used as an alternative to wheat paste flour.
\end{abstract}

Keywords: a-amylase, Lactobacillus bulgaricus, L. plantarum B110, local tube paste flour, reducing sugar

\begin{abstract}
ABSTRAK
Tepung umbi Indonesia meningkat kualitasnya dengan menggunakan $\alpha$-amilase yang menghidrolisa tepung amilosa menjadi glukosa dan maltosa. Monosakarida ini menyebabkan tepung dengan homogenitas lebih baik hampir seperti tepung terigu dan leb ih mudah dicerna. Penelitian ini ditujukan pada penguraian karbohidrat tepung pasta umbi dengan penambahan $\alpha$-amilase dari dua spesies Lactobacillus. Lactobacillus yang digunakan adalah Lactobacillus bulgaricus dan L. plantarum B110, sedangkan tepungnya adalah tepung lokal taro (Colocasia esculenta), gadung (Dioscorea hispida), ubi jalar (Ipomoea batatas) dan terigu (Triticum) yang digunakan sebagai pembanding. Aktivitas $\alpha$-amilase kasar dan gula reduksi dideteksi dengan metoda Dinitrosalicylic Acid (DNS). Data dianalis secara statistik de-ngan ANOVA. Hasil penelitian menunjukkan bahwa $\alpha$-amilase dari L. bulgaricus dan L. plantarum B110 su-dah terkarakterisi aktivitas optimum dan stabilitasnya. Kandungan gula reduksi pada tepung pasta taro, gadung, ubi jalar dan terigu dengan penambahan a-amilase L. bulgaricus terkarakterisasi meningkat secara berurutan sebesar 0,008; 0,006; 0,004; dan 0,01\%, sedangkan pada L. plantarum B110 meningkat 0,008; 0,008;0,008; dan 0,003\%. Berdasarkan hasil penelitian ini dapat disimpulkan bahwa peningkatan kandungan gula reduksi sebesar 0,004-0,008\% hasil degradasi karbohidrat pada tepung pasta umbi lokal dengan penambahan $\alpha$-amylase L. bulgaricus lebih tinggi dibandingkan pada tepung pasta terigu yang peningkatannya sebesar $0,001 \%$, sedangkan peningkatan gula reduksi sebesar $0,008 \%$ pada tepung pasta umbi dengan $\alpha$-amylase L. plantarum B110 lebih tinggi dibandingkan pada tepung terigu dengan peningkatan sebesar 0,003\%, sehingga tepung pasta umbi lokal dapat digunakan sebagai alternatiftepung pasta terigu.
\end{abstract}

Kata kunci: a-amilase, gula reduksi, Lactobacillus bulgaricus, L. plantarum B110, tepung pasta umbi lokal

The manuscript has been presented in The First International Symposium of JSPS Alumni Association of Indonesia, October 27-28 ${ }^{\text {th }}$ 2017, Cibodas-Indonesia

*Corresponding Author: E-mail: tatikkhusni@yahoo.com 


\section{INTRODUCTION}

Indonesian local tuber flour in both powder and paste improves in homogenecity almost like wheat flour by using $\alpha$-amylase to make the flour able to be digested more easily by human intestine. The quality of tuber flour can be improved by the addition of aamylase. Tuber paste flour were made by using local tubers of taro or Colocasia esculenta, gadung or Dioscorea hispida and sweet potato or Ipomoea batatas, and those pasta flour can be used as basic material for producing baby food and many types of tuber cakes.

a-Amylase was produced from bacteria (Moradi et al., 2014) including lactic acid bacteria (LAB). It was reported that there were several types of amylolytic lactic acid bacteria, mainly: L. plantarum S 21, L. fermentum 04BBA19 and $L$. fermentum Ogi E1 (Fossi et al., 2014; Kapienjai et al., 2015; Santoyo et al., 2003). The addition of $\alpha$-amylase cause flour to increase in quality (Santoyo et al., 2003; SongréOuattara et al., 2009). The a-amylase in flour catalysed amylose to monosaccharides of glucose and maltose (Sharma and Satyanarayana, 2013; Songré-Ouattara et al., 2009). The addition of $\alpha$ amylase to flour from LAB which hidrolyses amylose to glucose and maltose were more digestible in human intestine (Singh et al., 2015; Kapienjai et al., 2015).

The glucose and maltose contents in flour by the addition of $\alpha$-amylase depend on the type of flour and the $\alpha$-amylase concentration used (Savitri and Bhalla, 2013; Kapienjai et al., 2015). Different type of tuber flour contain different amylose concentration (do Esperito-Santo et al., 2014; Songré-Ouattara et al., 2009). Different concentration of $\alpha$-amylase resulted in diferent amylose hidrolysis by $\alpha$-amylase to glucose and maltose (Savitri and Bhalla, 2013; Songré-Ouattara et al., 2009).

The contents of glucose and maltose in the tuber paste flour by the addition of $\alpha$-amylase from Lactobacillus bulgaricus and Lactobacillus plantarum B110 were not known yet. To make tuber flour increase in homogenecity, the tuber flour could be added with $\alpha$-amylase from lactic acid bacteria as safe bacteria, with the wheat flour used as a comparison. This research aimed at investigating the carbohydrate degradation of tuber paste flour by the addition of $\alpha$-amylases from two Lactobacillus species namely Lactobacillus bulgaricus and Lactobacillus plantarum B110.

\section{MATERIALS AND METHODS}

\section{Materials}

Materials used were flour of taro or Colocasia esculenta from farmers at Ratu-Sukabumi harbour, gadung or Dioscorea hispida and sweet potato or Ipomoea batatas from farmers in Simpenan Sukabumi with commercial wheat or Triticum (Segitiga Biru, Indonesia) as comparison. L. plantarum B110 indigenous as indigenous lactic acid bacteria (LAB) identified molecularly was isolated from traditional fermented vegetable in Bogor, and Lactobacillus bulgaricus was obtained from Microbial Culture Collection, Research Centre for Biology, Indonesian Institute of Sciences.

\section{Subculture Lactobacillus plantarum B110 Indige- nous and Lactobacillus bulgaricus}

L. plantarum B110 as indigenous lactic acid bacteria (LAB) was identified molecularly and isolated from traditional fermented vegetable in Bogor, with Lactobacillus bulgaricus from the Microbial Culture Collection, Microbiology Division, Research Centre for Biology, Indonesian Institute of Sciences. The subcultures of those lactic acid bacteria used de mann rogosa sharpe (MRS) media which contain $1 \%$ of peptone (Bacto TM211677, United States), $0.8 \%$ of beef extract (Himedia RM002-500G, Germany), $0.4 \%$ of yeast extract (Bacto TM 212750, United States), 1\% of glucose (Merck 1.08337.1000, Germany), $0.1 \%$ of tween 80 (Merck 8.22187.0500, Germany), $0.5 \%$ of natrium acetate (Merck 1.06268 . 0250, Germany), $0.2 \%$ of triamonium citrate (Sigma A1332-100G, United States), $0.02 \%$ of magnesium sulphate monohydrate (Merck 1.05886.0500, Germany), $0.005 \%$ of mangan sulphate tetrahidrate (Merck 1.02786.1000, Germany), and $0.2 \%$ of dinatrium hydrogen phosphate dehydrate (Merck 1.0658 0.0500, Germany). The subcultured L. plantarum and $L$. bulgaricus were then incubated at $37^{\circ} \mathrm{C}$ in an incubator (Isuzu incubator Himawari, Y3556528677, Japan).

\section{Tube paste flour}

The three local tuber flour of taro or Colocasia esculenta, gadung or Dioscorea hispida and sweet potato or Ipomoea batatas were used as materials in production of tube paste flour, and as a comparison, wheat or Triticum was used. The tube flour was heated at $70^{\circ} \mathrm{C}, 10$ minutes to form paste flour.

\section{Carbohydrate degradation of wheat and local tube paste flour by the addition of $\alpha$-amylase}

The $5 \mathrm{~g}$ of each tube flour (wheat, taro, gadung and sweat potato) was soluted in $50 \mathrm{~mL}$ of aquades, heated, homogenised by thermomagnetic stirrer (Sibata $\mathrm{MGH}-320$, Japan) at $70^{\circ} \mathrm{C}$ for 10 minutes to form paste flour, added with $1 \mathrm{U} / \mathrm{mL}$ for each $L$. bulgaricus and $L$. plantarum B110 crude amylase, and incubated in a rotary shaker (V-Tech VTRS-1, Model: Platform Size $\mathrm{CM}$, India) at $37^{\circ} \mathrm{C}$ for 24 hours. 
a-Amylase isolation (Sharma and Satyanarayana, 2013)

Each of L. plantarum B110 and L. bulgaricus suspension was subcultured into $50 \mathrm{~mL}$ of MRSB media and incubated at $37^{\circ} \mathrm{C}$ for 24 hours in an incubator. L plantarum B110 or L. bulgaricus crude $\alpha$-amylase were isolated by subculturing $2 \%$ of lactic acid bacteria in $25 \mathrm{~mL}$ of sterilised glucose MRSB media (Merck, Germany) was modified with $2 \%$ of soluble starch (Merck, Germany) $6 \mathrm{pH}$, and the incubation was carried out for 24 hours at $37^{\circ} \mathrm{C}$ by using an incubator, and centrifuged in $9000 \mathrm{rpm}$ for 10 minutes at $4^{\circ} \mathrm{C}$ (Kubota 5910, Japan). Each crude $\alpha$-amylase was then tested to investigate its $\alpha$ amylase activity.

\section{Activity of $\alpha$-amylase (Bernfeld, 1955)}

The activity of $\alpha$-amylase was measured by using a DNS method. The $50 \mu$ crude $\alpha$-amylase was mixed with $50 \mu \mathrm{l}$ of $1 \%$ of soluble starch with 5.0-8.0 pH, homogenised by vortex (Sibata MGH320), incubated in waterbath (Memmert, Japan) at $35-65^{\circ} \mathrm{C}$ for 10 minutes, added with $100 \mu \mathrm{l}$ DNS reagen (Sigma D0550-100G, United States), homogenised, heated at $100^{\circ} \mathrm{C}$ for 5 minutes, poured with $800 \mu \mathrm{l}$ of aquades and revortexed. After the solution cooled, the absorbance was read at $\lambda 540$ by using spectrophotometer UV-Vis (Shimadzu UV-1700 Pharmaspec, Japan). The a-amylase activity unit was measured as the amount of enzyme in which the reaction produced the same product with $1 \mu \mathrm{mol}$ glucose per minute at the condition measured.

\section{$\alpha$-Amylase activity optimisation in various $\mathrm{pH}$ and temperatures (Wang et al., 2018)}

Optimisation of $\alpha$-amylase from $L$. bulgaricus and $L$. plantarum $\mathrm{B} 110$ in various $\mathrm{pH}$ detected by $\mathrm{pH}$ meter (Horiba pH 1100 Scientific, Japan), at incubation time for 10 minutes was conducted at various $\mathrm{pH}$ of $5.0,5.5,6.0,6.5,7.0,7.5$ and 8.0. The highest a-amylase activity at certain $\mathrm{pH}$ indicated the $\alpha$ amylase optimum activity. Optimisation of those $\alpha$ amylase activities in various temperatures in $10 \mathrm{mi}-$ nutes incubation was conducted at various temperatures of $35,40,45,50,55,60$ and $65^{\circ} \mathrm{C}$. The highest $\alpha$-amylase activity at certain temperature indicated the $\alpha$-amylase optimum activity.

Stability of $\alpha$-amylase in various $\mathrm{pH}$ and temperatures (Sharma and Satyanarayana, 2013 modified)

The a-amylase stability from $L$. bulgaricus and L. plantarum B110 was detected by measuring the relative activity of $\alpha$-amylase in various $\mathrm{pH}$ of 5.0 , $5.5,6.0,6.5,7.0,7.5$ and 8.0 in 60 minute incubation time, at the temperatures of $50^{\circ} \mathrm{C}$. The $\geq 50 \%$ relative activity of $\alpha$-amylase was defined as stability of the $\alpha$-amylase at a certain $\mathrm{pH}$ range. Stability of the two $\alpha$-amylases was also investigated by measuring $\alpha$-amylase relative activity at various temperatures of $35,40,45,50,55,60$ and $65^{\circ} \mathrm{C}$, with $5.5 \mathrm{pH}$. The $\geq 50 \%$ a-amylase relative activity was defined as stability of $\alpha$-amylase at a certain temperature range.

\section{Reducing sugar (Miller, 1959)}

Reducing sugar was measured by using a DNS method. Reducing sugar (\%) was measured by using the standard curve equation of glucose solution. Carbohydrate degradation in tube flour of wheat, taro, gadung, and sweet potato (with or without the addition of L. bulgaricus or L. plantarum B110 crude $\alpha$-amylase) was centrifuged for 10 minutes at 9000 $\mathrm{rpm}$ at $4^{\circ} \mathrm{C}$. The $100 \mu \mathrm{l}$ of tube flour treated was poured into $100 \mu \mathrm{l}$ DNS reagent, homogenised, and the mixture was heated at $100^{\circ} \mathrm{C}$ for 5 minutes, poured into $800 \mu \mathrm{l}$ aquadest, and revortexed. The mixture was then left in a minute, untill the absorbance was read at $\lambda: 540$ by using spectrophotometer UV-Vis.

$\operatorname{RSD}(\%)=\frac{\text { glucose concentration }(\mathrm{mg} / \mathrm{mL})}{\text { sample weight }(\mathrm{mg})}$

x Volume of reaction total $(\mathrm{mL}) \times 100 \%$

where, RDS= Reducing sugar concentration.

\section{Statistical analysis}

Data were statistically analysed using analysis of variance (ANOVA) with completely randomised design (CRD), and further analysis was done using the Duncan test to compare the effects of each treatment. Data analysis was conducted by using SPSS 16.0.

\section{RESULTS AND DISCUSSION}

\section{a-Amylase activity optimisation}

The results of this research show that $L$. bulgaricus $\alpha$-amylase activity at $\mathrm{pH}$ 5.0-8.0 had a value of $0.243-0.539 \mathrm{U} / \mathrm{mL}$ and the $L$. bulgaricus $\alpha$-amylase optimum activity was reached at $50^{\circ} \mathrm{C}$ with a value of $0.539 \mathrm{U} / \mathrm{mL}$, with $6 \mathrm{pH}, 0.539 \mathrm{U} / \mathrm{mL}(P<0.05)$, while the $L$. plantarum B110 a-amylase had a value of $0.403-0.641 \mathrm{U} / \mathrm{mL}$ and the $L$. plantarum B110 $\alpha$ amylase optimum activity was $50^{\circ} \mathrm{C}$ with a value of $0.533 \mathrm{U} / \mathrm{mL}$, with $7.0 \mathrm{pH}, 0.641 \mathrm{U} / \mathrm{mL} \quad(P<0.05)$ (Table 1). 
Table 1. The activities of $\alpha$-amylase from $L$. bulgaricus and $L$. plantarum B110 at various $\mathrm{pH}$ and temperatures

\begin{tabular}{|c|c|c|c|c|c|c|}
\hline \multirow{2}{*}{ No. } & \multirow{2}{*}{$\mathrm{pH}$} & \multicolumn{2}{|c|}{ Activity of $\alpha$-Amylase $(\mathrm{U} / \mathrm{mL})$} & \multirow{2}{*}{$\begin{array}{c}\text { Temperature } \\
\left({ }^{\circ} \mathrm{C}\right)\end{array}$} & \multicolumn{2}{|c|}{ Activity of $\alpha$-Amylase $(\mathrm{U} / \mathrm{mL})$} \\
\hline & & L. bulgaricus & L. plantarum B110 & & L. bulgaricus & L. plantarum B110 \\
\hline 1 & 5.0 & $0.243^{a} \pm 0.018$ & $0.403^{\mathrm{a}} \pm 0,278$ & 35 & $0.254^{\mathrm{a}} \pm 0.029$ & $0.214^{0} \pm 0.178$ \\
\hline 2 & 5.5 & $0.468^{\circ} \pm 0.180$ & $0.439^{\mathrm{a}} \pm 0,151$ & 40 & $0.277^{\mathrm{a}} \pm 0.055$ & $0.262^{0} \pm 0.117$ \\
\hline 3 & 6.0 & $0.539^{\mathrm{D}} \pm 0.040$ & $0.533^{\mathrm{a}} \pm 0.011$ & 45 & $0.371^{\mathrm{D}} \pm 0.084$ & $0.293^{\mathrm{ad}} \pm 0.074$ \\
\hline 4 & 6.5 & $0.374^{\mathrm{C}} \pm 0.074$ & $0.578^{\mathrm{a}} \pm 0.062$ & 50 & $0.539^{\mathrm{C}} \pm 0.041$ & $0.533^{\mathrm{a}} \pm 0.011$ \\
\hline 5 & 7.0 & $0.371^{\mathrm{c}} \pm 0.191$ & $0.641^{\mathrm{a}} \pm 0.421$ & 55 & $0.280^{\mathrm{a}} \pm 0.023$ & $0.227^{\mathrm{D}} \pm 0.086$ \\
\hline 6 & 7.5 & $0.243^{\mathrm{a}} \pm 0.005$ & $0.505^{\mathrm{a}} \pm 0.386$ & 60 & $0.270^{\mathrm{a}} \pm 0.031$ & $0.174^{\mathrm{D}} \pm 0.050$ \\
\hline 7 & 8.0 & $0.240^{\mathrm{a}} \pm 0.013$ & $0.419^{\mathrm{a}} \pm 0.238$ & 65 & $0.251^{\mathrm{a}} \pm 0.025$ & $0.144^{\mathrm{D}} \pm 0.036$ \\
\hline
\end{tabular}

Note: The different letters in the same column show a significant difference $(P<0.05)$

The difference in optimum $\alpha$-amylase activity at different $\mathrm{pH}$ and temperature levels between $L$. bulgaricus and $L$. plantarum B110 $\alpha$-amylases was caused by different species producing $\alpha$-amylase of the two lactic acid bacteria. It was reported that the different amylolytic lactic acid bacteria species might have resulted in different $\alpha$-amylase optimum activities of the two bacteria (Santoyo et al., 2003; Tallapragada et al., 2018).

\section{Stability of $\alpha$-amylase}

The activity of $L$. bulgaricus $\alpha$-amylase at $60 \mathrm{mi}$ nute incubation time with $\mathrm{pH}$ in the range of 5.0-8.0 had a value of $0.044-0.123 \mathrm{U} / \mathrm{mL}$ and the relative activity of $\alpha$-amylases was in the range of 35.684$100 \%$ (Table 2); while at the temperature ranging between $35-65^{\circ} \mathrm{C}$, it was $0.05-0.08 \mathrm{U} / \mathrm{mL}$ with the $\alpha-$ amylase relative activity was in the range of 54.57$100 \%$ (Table 3 ). The stability of $L$. bulgaricus $\alpha$ amylase with $\geq 50 \% \alpha$-amylase relative activity in 60 minute incubation time was reached at $\mathrm{pH}$ ranging between 5.0-7.0 $(0.061-0.123 \mathrm{U} / \mathrm{mL})$ with the relative activities were $50.019-100 \%$ (Table 2), while that at temperature in the range of $35-65^{\circ} \mathrm{C}(0.046-$ $0.084 \mathrm{U} / \mathrm{mL}$ ) with the relative activity between $54.571-100 \%$ (Table 3).

The activity of $L$. plantarum B110 $\alpha$-amylase at 5.0-8.0 pH within 60 minute incubation time was in the range of $0.059-0.117 \mathrm{U} / \mathrm{mL}$ with $\alpha$-amylase relative activity was $50.43-100 \%$ (Table 2), while at the temperature of $35-55^{\circ} \mathrm{C}$, it was between 0.031 $0.100 \mathrm{U} / \mathrm{mL}$ with the relative activity between $31.000-100 \%$ (Table 3).

The stability of $L$. plantarum B110 a-amylase with relative activity $\geq 50 \%$ in 60 minute incubation time was reached at $\mathrm{pH}$ in the range of 5.0-8.0 (0.059-0.117 U/mL) with $\alpha$-amylase relative activity around $50.43-100 \%$ (Table 2), while at the temperature in the range of $35-55^{\circ} \mathrm{C}$, it was $0.055-0.100 \mathrm{U} /$ $\mathrm{mL}$ with relative activity between $55.000-100 \%$ (Table 3).

The different $\alpha$-amylase stabilities measured based on their relative activity at the range of certain $\mathrm{pH}$ and temperatures of $\alpha$-amylase from $L$. bulgaricus and L. plantarum B110 were caused by the different optimum activity of $\alpha$-amylase from the two lactic acid bacteria species. It was reported that the different species of lactic acid bacteria producing $\alpha$ amylase might have resulted in the different optimum $\alpha$-amylase activities from the two lactic acid bacteria species (Kanpiengjai et al., 2015; Santoyo et al., 2003; Shongre-Quottara et al., 2009).

\section{Reducing sugar of wheat and local tube paste flour by the addition of $\alpha$-amylase}

The reducing sugar content of the paste flour of sweet potato, gadung, and taro by the addition of $\alpha$ amylase from $L$. bulgaricus increased by 0.008 , 0.006 and $0.004 \%$, respectively (Table 4 ), while that of the three paste flours by the addition of $\alpha$-amylase from L. plantarum B110 increased by $0.008 \%$ (Table 4). The reducing sugar content of wheat paste flour by the addition of $\alpha$-amylase from $L$. bulgaricus increased $0.001 \%$ (Table 4 ), while the reducing sugar content of wheat paste flour by the addition of $\alpha$-amylase from $L$. plantarum B110 increased by $0.003 \%$ (Table 4 ).

The reducing sugar content of paste flour from sweet potato, gadung and taro by the addition of $\alpha$ amylase from $L$. bulgaricus which increase by 0.008 , 0.006 , and $0.004 \%$, respectively was higher than that of wheat paste flour which increase by $0.01 \%$ (Table 4), and the reducing sugar content of the paste flour of sweet potato, gadung and taro by the addition of $\alpha$-amylase from $L$. plantarum B110 which increased $0.008 \%$ for each was higher than that of wheat paste flour which showed a $0.003 \%$ increase.

The tube paste flour by the addition of each $\alpha$ amylase from $L$. bulgaricus or a-amylase from $L$. plantarum B110 increased the homogenecity of the flour, because of the higher reducing sugar level increases in the tube paste flour by the addition of $\alpha$ amylase than that of wheat paste flour,

The higher reducing sugar level increases in the paste flour of sweet potato, gadung and taro by the addition of $\alpha$-amylase from $L$. bulgaricus or $\alpha$ amylase from $L$. plantarum B110 than that in wheat paste flour was because the content of carbohydrate in sweet potato, gadung and taro flour was higher than that in wheat flour. 
Table 2. The relative activities of $\alpha$-amylase from L. bulgaricus and L. plantarum B110 at various $\mathrm{pH}$

\begin{tabular}{cccccc}
\hline \multirow{2}{*}{ No. } & $\mathrm{pH}$ & \multicolumn{2}{c}{ Activity of $\alpha$-Amylase $(\mathrm{U} / \mathrm{mL})$} & \multicolumn{2}{c}{ Relative Activity of $\alpha$-Amylase $(\%)$} \\
\cline { 3 - 6 } & & L. bulgaricus & L.plantarum B110 & \multicolumn{1}{c}{ L. bulgaricus } & L. plantarum B110 \\
\hline 1 & 5.0 & 0.118 & 0.101 & $96.513^{\mathrm{a}} \pm 0.025$ & $86.32^{\mathrm{a}} \pm 0.340$ \\
2 & 5.5 & 0.123 & 0.117 & $100.000^{\mathrm{a}} \pm 0.134$ & $100.00^{\mathrm{a}} \pm 0.410$ \\
3 & 6.0 & 0.061 & 0.067 & $50.019^{\mathrm{a}} \pm 0.013$ & $57.26^{\mathrm{a}} \pm 0.150$ \\
4 & 6.5 & 0.074 & 0.059 & $60.093^{\mathrm{a}} \pm 0.178$ & $50.43^{\mathrm{a}} \pm 0.227$ \\
5 & 7.0 & 0.092 & 0.066 & $75.203^{\mathrm{a}} \pm 0.404$ & $56.41^{\mathrm{a}} \pm 0.081$ \\
6 & 7.5 & 0.052 & 0.059 & $42.270^{\mathrm{a}} \pm 0.042$ & $50.43^{\mathrm{a}} \pm 0.141$ \\
\hline
\end{tabular}

Note: The different letters in the same column show a significant difference $(P<0.05)$

Table 3. The relative activities of $\alpha$-amylase from $L$. bulgaricus and $L$. plantarum B110 at various temperatures

\begin{tabular}{cccccc}
\hline \multirow{2}{*}{ No. } & \multirow{2}{*}{ Temperature $\left({ }^{\circ} \mathrm{C}\right)$} & \multicolumn{2}{c}{ Activity of $\alpha$-Amylase $(\mathrm{U} / \mathrm{mL})$} & \multicolumn{2}{c}{ Relative Activity of $\alpha$-Amylase $(\%)$} \\
\cline { 3 - 6 } & & L. bulgaricus & L. plantarum B110 & L. bulgaricus & L. plantarum B110 \\
\hline 1 & 35 & 0.051 & 0.069 & $60.818^{\mathrm{D}} \pm 0.124$ & $69.00^{\mathrm{a}} \pm 0.108$ \\
2 & 40 & 0.050 & 0.081 & $60.250^{\mathrm{D}} \pm 0.024$ & $81.00^{\mathrm{a0}} \pm 0.143$ \\
3 & 45 & 0.046 & 0.100 & $54.571^{\mathrm{D}} \pm 0.024$ & $100.00^{\mathrm{a}} \pm 0.312$ \\
4 & 50 & 0.060 & 0.066 & $71.607^{\mathrm{D}} \pm 0.036$ & $66.00^{\mathrm{a0}} \pm 0.026$ \\
5 & 55 & 0.054 & 0.055 & $64.225^{\mathrm{D}} \pm 0.072$ & $55.00^{\mathrm{a0}} \pm 0.132$ \\
6 & 60 & 0.084 & 0.043 & $100.000^{\mathrm{a}} \pm 0.110$ & $43.00^{\mathrm{a0}} \pm 0.119$ \\
7 & 65 & 0.048 & 0.031 & $57.411^{\mathrm{D}} \pm 0.056$ & $31.00^{\mathrm{a0}} \pm 0.106$ \\
\hline
\end{tabular}

Note: The different letters in the same column show a significant difference $(P<0.05)$

Table 4. The increase of reducing sugar contents in the wheat and local tuber paste flour by the addition of a-amylase from L. bulgaricus and L. plantarum B110

\begin{tabular}{|c|c|c|c|c|c|}
\hline \multirow[b]{2}{*}{ No. } & \multirow[b]{2}{*}{$\begin{array}{c}\text { Paste Flour (PF) with and } \\
\text { without Addition of } \alpha \text {-amylase }\end{array}$} & \multicolumn{2}{|c|}{ a-Amylase from L. bulgaricus } & \multicolumn{2}{|c|}{ a-Amylase from L. plantarum B110 } \\
\hline & & $\begin{array}{l}\text { Reducing Sugar } \\
\text { Content }(\%)\end{array}$ & $\begin{array}{c}\text { Increase of } \\
\text { Reducing Sugar } \\
\text { Content (\%) }\end{array}$ & $\begin{array}{l}\text { Reducing Sugar } \\
\text { Content (\%) }\end{array}$ & $\begin{array}{c}\text { Increase of } \\
\text { Reducing Sugar } \\
\text { Content (\%) }\end{array}$ \\
\hline 1 & Wheat pas te flour (W-PF) & $0.020^{\mathrm{aO}} \pm 0.0000$ & 0.001 & $0.025^{\circ} \pm 0.0011$ & 0.003 \\
\hline 2 & W-PF+a-Amylase & $0.021^{\mathrm{a}} \pm 0.0006$ & & $0.028^{\mathrm{a}} \pm 0.0000$ & \\
\hline 3 & Sweet potato paste flour (SP-PF) & $0.013^{a} \pm 0.0000$ & 0.008 & $0.015^{\mathrm{e}} \pm 0.0006$ & 0.008 \\
\hline 4 & SP-PF+a-Am ylase & $0.021^{\mathrm{a}} \pm 0.0006$ & & $0.023^{\mathrm{c}} \pm 0.0000$ & \\
\hline 5 & Taro paste flour (T-PF) & $0.015^{\mathrm{c}} \pm 0.0006$ & 0.004 & $0.017^{\mathrm{a}} \pm 0.0000$ & 0.008 \\
\hline 6 & T-PF+a-Amylase & $0.019^{\mathrm{D}} \pm 0.0000$ & & $0.025^{\mathrm{D}} \pm 0.0000$ & \\
\hline 7 & Gadung paste flour (G-PF) & $0.006^{\mathrm{e}} \pm 0.0000$ & 0.006 & $0.014^{\mathrm{e}} \pm 0.0006$ & 0.008 \\
\hline 8 & G-PF+a-Amylase & $0.012^{\mathrm{a}} \pm 0.0000$ & & $0.022^{\mathrm{C}} \pm 0.0000$ & \\
\hline
\end{tabular}

Note: The different letters in the same column show a significant difference $(P<0.05)$

It was reported that the reducing sugar level of flour resulting from the lactic acid bacteria amylase activity in carbohydrate degradation was affected by the carbohydrate contents of the flour (do EsperitoSanto et al., 2014; Kanpiengjai et al., 2015; Santoyo et al., 2003).

\section{CONCLUSION}

Carbohydrate degradation shown by the increases of reducing sugar contents which was about $0.004-0.008 \%$ in local tuber paste flour by the addition of the characterized $\alpha$-amylase from $L$. bulgaricus was higher than that of wheat which was $0.001 \%$ sugar content, while the increase of reducing sugar contents in the flour by the addition of a-amylase from L. plantarum B110 which was $0.008 \%$ was higher than that in wheat which was
$0.003 \%$, so that local tuber paste flour can be used as an alternative of wheat paste flour.

\section{ACKNOWLEDGEMENT}

The authors would like to thank to the Life Sciences Deputy, Indonesian Institute of Sciences for the Project of DIPA Priority in the Aplied Bioresources, Research Center for Biology, for this research funding, and Mrs. Desy Septiani S.Si. for her assistance in the Laboratory.

\section{REFERENCES}

Bernfeld P. 1955. Amylase, $\alpha$ and $\beta$. Methods in Enzymology. 149-158. Science and Education Publishing. DOI: 10.1016/0076-6879(55)010215. 
do Esperito-Santo AP, Mouquet-Rivier C, Humblot C, Cazevieille C, Icard Vemiere C, Socrol CR, Guyot GP. 2014. Influence of cofermentation by amylolytic Lactobacillus strains and probiotic bacteria on the fermentation process, viscosity and microstructure of gruels made of rice, soy milk and passion fruit fiber. Food Res Int 57: 104-113. DOI: 10.1016/j.foodres.2014.01.028.

Fossi BT, Tavea F, Fontem LA, Ndjouenkeu R, Wanji S. 2014. Microbial interactions for enhancement of a-amylase production by Bacillus amyloliquefaciens 04BBA15 and Lactobacillus fermentum 04BBA19. Biotechnol Reports 4: 99106. DOI: 10.1016/j.btre.2014.09.004.

Kanpiengjai A, Lumyong S, Nguyen HT, Haltrich D. 2015. Characterization of a maltose-forming $\alpha-$ amylase from an amylolytic lactid acid bacterium Lactobacillus plantarum S21. J Mol Catal B: Enzymatic 120: 1-8. DOI: 10.1016/j.molcatb. 2015.06.010.

Miller GL. 1959. Use of dinitrosalicylic acid reagent for determination of reducing sugar. Anal Chem 31: 426-428. DOI: 10.1021/ac60147a030.

Moradi M, Shariati P, Tabandeh F, Yakhcali B, Khaniki GB. 2014 Screening and isolation of powerful amylolytic bacterial strains. Int J Curr Microbiol Appl Sci 3: 758-768.

Santoyo MC, Loiseau G, Sanoja RR, Guyot JP. 2003. Study of starch fermentation at low $\mathrm{pH}$ by Lactobacillus fermentum Ogi $\mathrm{E} 1$ reveals uncoupling between growth and $\alpha$-amylase production at $\mathrm{pH}$ 4.0. Int $\mathrm{J}$ Food Microbiol 80: 7787. DOI: 10.1016/S0168-1605(02)00140-X.

Savitri, Bhalla TC. 2013. Characterization of bhatooru, a traditional fermented food of himachal pra- desh: Microbiological and biochemical aspects 3 Biotech 3: 247-254. DOI: 10.1007/s13205012-0092-2.

Sharma A, Satyanarayana T. 2013 Microbial acidstable-amylases: Characteristics, genetic engineering and applications - a review. Proc Biochem 48: 201-211. DOI: 10.1016/j.procbio.201 2.12.018.

Singh K, Srivastava G, Talat M, Srivastava ON, Kayastha AM. 2015. a-Amylase immobilization onto functionalized graphenenano sheets as scaffolds: Its characterization, kinetics and potential applications in starch based industries. Biochem Biophys Reports 3: 18-25. DOI: 10.1016/j.bbrep.2015.07.002.

Songré-Ouattara LT, Mouquet-Rivier C, Icard-Vernière $\mathrm{C}$, Rochette I, Diawara $\mathrm{B}$, Guyot JP. 2009. Potential of amylolytic lactic acid bacteria to replace the use of malt for partial starch hydrolysis to produce African fermented pearl millet gruel fortified with groundnut. Int J Food Microbiol 130: 258-264. DOI: 10.1016/j.ijfoodmicro.20 09.02.002.

Tallapragada P, Rayavarapu B, Rao P.P, Ranganath NN, Veerabhadrappa PP. 2018. Screening of potential probiotic lactic acid bacteria and production of amylase and its partial purification. J Genetic Engineering Biotechnol 16: 357362. DOI: 10.1016/j.jgeb.2018.03.005.

Wang J, Li J, Lu F. 2018. Molecular cloning and biochemical characterization of an $\alpha$-amylase family from Aspergillus niger. Electronic J Biotechnol 32: 56-62. DOI: 10.1016/j.ejbt.2018.01. 004. 